\section{Sermons for Reference.}

Barrett (G. S.), Temptation of Christ, 22.

Belfrage (H.), Sacramental Addresses, 370 .

Bernard (J. II.), Via Domini, I45.

Brown (A.), God's Great Salvation, I64.

Burcler (H. F.), Sermons, 62.

Colenso (J. W.), Natal Sermons, ii. $S_{4}$.

Davies (D. ), Talks with Men, Women, and Children, iii. 22 r.

Dewhurst (L. M.), King and His Servants, 78 .
Fairbairn (A. M.), Christ in the Centuries, 123.

How (W. W.), Plain Words, ii. 103 .

Manning (H. E.), Sermons, i. 287.

Matheson (G.), Moments on the Mount, 204.

Meyer (F. B.), Way into the Holiest, 87.

Milligan (W.), Resurrection of Our Lord, 304.

Newman (J. H.), Parochial Sermons, iii. 156.

Spurgeon (C. H.), My Sermon Notes, iv. 336.

Trench (R. C.), Studies on the Authorized Version, 61.

Westcott (B. F.), Victory of the Cross, 55 .

\title{
Magic and Religion.
}

\section{By the Rev. William Marivick, Old Calabar.}

THE first edition of The Golden Bough (1890) had for sub-title, 'A Study in Comparative Religion.' The second, revised and enlarged, edition has for sub-title, 'A Study in Magic and Religion.' The change is significant. While Mr. Frazer's views regarding the priesthood of Aricia, which forms the central theme, and the general interpretation which, following W. Mannhardt, he had given of the ceremonies observed by the European peasantry in spring, at midsummer, and at harvest, remain much as they were, his views regarding the relation of magic to religion have undergone a certain amount of change, or at least have become clearer. 'When I first wrote this book,' he says (G.B. ${ }^{2}$ vol. i. p. xvi), 'I failed, perhaps inexcusably, to define even to myself my notion of religion, and hence was disposed to class magic loosely under it as one of its lower forms. ... I have come to agree with Sir A. C. Lyall and Mr. F. B. Jevons in recognizing a fundamental distinction and even opposition of principle between magic and religion. More than that, I believe that in the evolution of thought, magic, as representing a lower intellectual stratum, has probably everywhere preceded religion. I do not claim any originality for this latter view. It has been already plainly suggested, if not definitely formulated, by Professor $\mathrm{H}$. Oldenberg in his able book, Die Religion des $V e d a$, and for aught I know it may have been explicitly stated by many others before and since him. I have not collected the opinions of the

1 The Golden Bough : a Study in Magic and Religion. By J. G. Frazer, D.C.L., LL.D., Litt.D. Second edition, revised and enlarged; in 3 vols. London: Macmillan \& Co. Ltd., Igoo. learned on the subject, but have striven to form my own directly from the facts. And the facts which bespeak the priority of magic over religion are many and weighty. Some of them the reader will find stated in the following pages; but the full force of the evidence can only be appreciated by those who have made a long and patient study of primitive superstition. . . That all my readers should agree either with my definition of religion or with the inferences I have drawn from it, is not to be expected. But I would ask those who dissent from my conclusions to make sure that they mean the same thing by religion that I do; for otherwise the difference between us may be more apparent than real.'

It is in attempting to explain the Arician priest's title, 'the King of the Wood,' that Mr. Frazer is at once brought into touch with the problem of magic and its relation to religion. Sec. 2 of chap. I-formerly entitled 'Primitive Man and the Supernatural,' is now called 'Magic and Religion'-is enlarged from 23 pp. to $\mathbf{I} \mathbf{I}$, and contains much new matter of importance. Ancient kings were revered, in many cases not merely as priests, that is, as intercessors between man and god, but as themselves gods, able to bestow upon their subjects and worshippers those blessings which are commonly supposed to be beyond the reach of man, and are sought, if at all, only by prayer and sacrifice offered to superhuman and invisible beings. Thus kings are often expected to give rain and sunshine in due season, to make the crops grow, and so on. Strange as this expectation appears to us, it is quite of a piece with early modes of thought. A 
savage hardly conceives the distinction commonly drawn by more advanced peoples between the natural and the supernatural (G.B.' i. 8, 2 i. 8, 9). Mr. F. B. Jevons argues ably for the contrary view in his Introduction to the History of Religion ( 1896 ), chap. 3, 'The Supernatural.' He says, 'From the beginning there were some sequences of phenomena, some laws which man had observed, and the occurrence of which he took as a matter of course and regarded as natural ' (p. I \&). '. . . Laws on which man could count and sequences which he habitually initiated and controlled were natural. It was the violation of these sequences and the frustration of his expectations by which the belief in supernatural power was not created but was first called forth' (p. 19). Of course this distinction is to be regarded as implicit rather than explicit, as words for 'natural' and 'supernatural ' do not exist in the languages of contemporary savages. Still, there are attempts to express what is abnormal or super-normal. Take, e.g., the Melanesian word 'mana.' Dr. Codrington deprecates the use of the word 'supernatural' with reference to it. It is unseen power which can be turned by man to his own benefit, as in the case of electricity or even wind. It is 'a power or influence not physical and in a way supernatural.' . . . It ' is not fixed in anything, and can be conveyed in almost anything ; but spirits, whether disembodied souls or supernatural beings, have it and can impart it ; and it essentially belongs to personal beings to originate it, though it may act through the medium of water, or a stone, or a bone.' Once more, it 'works to effect everything which is beyond the ordinary power of man outside the common process of nature,' etc. ${ }^{1}$ Mana belongs to 'the dynamic mode of conception.'

To the savage, who hardly conceives the distinction between the natural and the supernatural, 'the world,' Mr. Frazer goes on to say, ' is to a large extent worked by supernatural (sic) agents, that is, by personal beings acting on impulses and

${ }^{3}$ Dr. R. H. Codrington, The Melanesians, p. I I 9 , as quoted by Lady Welby in her interesting paper, "The Significance of Folk-Lore,' International Folk-Lore Congress, 1S91, Pafirs and Transactions, p. 397, in which she discusses the danger of the ambiguous use of words. See also A. Lang, Thi Making of Ritigion, and ed., pp. 197-200. Mr. Lang identifies mana with 'magical rapport,' or, more generally, with 'the uncanny, $\mathrm{X}$, the unknown,' which seems to be too vague. See also quotations from Codrington in C.B. ${ }^{2}$ i. pp. 65 and ${ }_{1} 38$. motives like his own, liable like him to be moved by appeals to their pity,' etc. 'In a world so conceived, he sees no limit to his power of influencing the course of nature to his own advantage. Prayers, promises, or threats may secure him fine weather and an abundant crop from the gods; and if a god should happen, as he sometimes believes, to become incarnate in his own person, then he need appeal to no higher being; he, the savage, possesses in himself all the powers necessary to further his own well-being and that of his fellowmen.

"This is one way in which the idea of a man-god is reached. But there is another. Side by side with the view of the world as pervaded by spiritual forces, primitive man has another conception in which we may detect a germ of the modern notion of natural law or the view of nature as a series of events occurring in an invariable order without the intervention of personal agency. The germ of which I speak is involved in that sympathetic magic, as it may be called, which plays a large part in most systems of superstition' (G.B. ${ }^{1}$ and ${ }^{2}$ i. 9). Here magic and religion are described as existing 'side by side,' religion apparently the earlier.?

In the new edition Mr. Frazer sets forth the 'fundamental principles' on which sympathetic magic is based-for it is a philosophy as well as an art. They seem to be reducible to two: '( $\mathrm{I}$ ) that like produces like, or that an effect resembles its cause; and (2) that things which have once been in contact, but have ceased to be so, continue to act on each other, as if the contact still persisted. On the first is based imitative or mimetic magic ; on the second, what may appropriately be termed sympathetic in the strict sense. In practice the two are often conjoined; or, to speak more exactly, while imitative magic may be practised by itself, sympathetic magic in the strict sense will generally be found to involve an application of the mimetic principle' (G.B.2 i, 9, I0). But 'sympathetic magic' is 'a question-begging epithet' (Jevons, I.H.R. p. 24).

Mr. Frazer then proceeds to illustrate the principles of sympathetic magic both in the wider and the narrower sense of the term (pp. Io-6o), and then says: 'In a few of the cases cited we have seen that the operation of spirits is assumed, and that an attempt is made to win their favour by

${ }^{2}$ But see G.B.2 i. pp. $70-7 \mathrm{I}$, for argument that magic is older than religion. 
prayer and sacrifice. But these cases are exceptional; they exhibit magic, tinged and alloyed with religion' (p. 6r). It might be as correct to say that they exhibit religion alloyed with magic (see pp. I6, I 9, 34, 42 (Indian sacrifice), 45 (Melanesian sacred stones). And it might be possible to multiply these 'exceptional cases.'

At p. 80 'the impatient reader who has quite forgotten' (as even the patient reader might be excused for doing) ' is respectfully reminded that we were led to plunge into the labyrinth of magic ... by a consideration of two different types of man-god. ... The two types may conveniently be distinguished as the religious and the magical man-god respectively. In the former, a being of an order different from and superior to man is supposed to become incarnate, for a longer or a shorter time, in a human body, manifesting his superhuman power and knowledge by miracles wrought and prophecies uttered through the medium of the fleshly tabernacle in which he has deigned to take up his abode. . . . On the other hand, a man-god of the magical sort is nothing but a man who possesses in an unusually high degree powers which most of his fellows arrogate to themselves on a smaller scale; for in rude society there is hardly a person who does not dabble in magic. Thus, whereas a man-god of the former or inspired type derives his divinity from a deity who has stooped to hide his heavenly radiance behind a dull mask of earthly mould, a man-god of the latter type draws his extraordinary power from a certain physical sympathy with nature.' But it turns out after all the labyrinthine wandering consequent on the consideration of two different types of man-god that 'the line between these two types of man-god, however sharply we may draw it in theory, is seldom to be traced with precision in practice, and in what follows I shall not insist on it ' $\left(G . B .{ }^{2}\right.$ i. $\left.8 \mathrm{r}\right)$.

IVe now turn back to P. 6r, where Mr. Frazer discusses the relation of magic (unalloyed with religion) to science. "Sympathetic magic... assumes that in nature one event follows another necessarily and invariably without the intervention of any spiritual or personal agency. Thus its fundamental conception is identical with that of modern science ; underlying the whole system is a faith, implicit but real and firm, in the order and uniformity of nature. . . The magician supplicates no higher power; he sues the favour of no fickle and wayward being; he abases himself before no awful deity. Yet his power, great as he believes it to be, is by no means arbitrary and unlimited. He can wield it only so long as he strictly conforms to the rules of his art, or to what may be called the laws of nature as conceived by him. .. Thus the analogy between the magical and the scientific conceptions of the world is close. ... The fatal flaw of magic lies not in its general assumption of a succession of events determined by law, but in its total misconception of the particular laws which govern that succession. . . A mistaken association of similar ideas produces imitative or mimetic magic; a mistaken association of contiguous ideas produces sympathetic magic in the narrower sense of the word. The principles of association are excellent in themselves, and indeed absolutely essential to the working of the human mind. Legitimately applied they yield science; illegitimately applied they yield magic, the bastard sister of science' (G.B.2 i. $6 \mathrm{I}, 62)$.

But the foundation of savage and scientific logic is the same, for it is the uniformity of nature. The savage has not indeed formulated the inductive methods, but he uses them all. The savage theory of causation is not fundamentally different from the scientific: it is only incomplete and exaggerated. The differences between savage and scientific logic are not formal but material. The errors of the early logician were extra-logical, and therefore were such as could be remedied by no process of logic, but only by wider experience. To speak of the savage's choice among innumerable possible causes, when he makes mistakes, as haphazard and illogical, is to misconceive the nature of logic.' 'It might be expected that, as it was only experience which could show what was impossible, so experience would suffice of itself to teach men this essential distinction. But as a matter of fact, experience by itself has done no such thing, as is shown by the simple fact that great as is the age and long as is the experience of the human race, the vast majority of its members have not yet learned from experience that like does not necessarily produce like; four-fifths of mankind, probably, believe in sympathetic magic, and therefore neither need nor can make any intellectual progress, while the progressive minority are precisely those from amongst

1 Sir A. C. Lyall seems to regard savages as devoid of logic (Asiatic Studies, and ed. (1884), p. 78). 
whom magic has been uprooted by its relentless foe, religion.' 1

The fallacy that things causally related must be similar to one another is 'a fallacy from which most savages, who in this may be taken as representing primitive man, have not yet escaped.' ${ }^{2}$ The means which the savage employs for the purposes of 'sympathetic magic' are 'precisely those used for the ordinary commonplace purposes of life both by him and by civilised man.' 'Sympathetic magic, which is the germ of all magic, does not therefore involve in itself the idea of the supernatural, but is simply the applied science of the savage.': MIr. Frazer's 'magic, unalloyed with religion,' seems practically equivalent to $\mathrm{Mr}$. Jevons' 'applied science of the savage.' The differences that emerge in their respective treatment of the relations of magic and religion are traceable to Mr. Frazer's dictum that the savage hardly conceives the distinction between the 'natural' and the 'supernatural' and to his hypothesis of two types of man-god. The dictum and the hypothesis affect Mr. Frazer's treatment of his study of magic and religion throughout the three volumes.

It is, I trust, no disparagement of the utility and the interest of this learned work as a repertory of facts, to say that the light bridges of hypotheses, as Mr. Frazer himself calls them, by which he attempts to colligate the facts, seem poised above, rainbow wise, instead of resting on solid foundations. ${ }^{*}$ If I may venture on a general criticism, I think Mr. Frazer hardly sifts his facts with sufficient care; sometimes omits to apply the canons of the higher criticism to some of his authorities, e.g. Plutarch's Isis and Osiris, whose version of the Osiris myth is 'immensely garbled and overlaid,' though its main lines 'can be seen through the clouds of comment, expansion, and transformation in a more connected and fuller form than elsewhere'; ${ }^{5}$ and reads into many of his facts more than the facts themselves warrant, or, when they are compared with other facts that may or can be adduced, ought legitimately to be inferred from them. One important

'Jevons, I.H.K. p. 33 ; cf. A. Lang, 'Mr. Frazer's Theory of Totemism,' Fortnightly Revici', June I\$99, p. IоI2.

2 Op cit. p. 34.

3 Jevons, 1.H.R., p. 35.

* See A. Lang's examinations of hypotheses in 'The Golden Bough,' in Fortnightly Review, Feb. and April 1901 .

${ }^{5}$ Authority and Archcology (1899), pp. 2 I 7 and 195. example under the last count may be adduced. In proceeding to give examples of 'human gods,' Mr. Frazer says: 'At the outset, it is well to note that in the sorcerer or miracle-monger pure and simple we have, as it were, the chrysalis out of which the full-blown god or king may sooner or later emerge. "The real gods at Tanna," says the Rev. Dr. Turner, "may be said to be the diseasemakers. It is surprising how these men are clreaded, and how firm the belief that they have in their hands the power of life and death." The means employed by these sorcerers to effect their fell purpose is sympathetic magic; they pick up the refuse of a man's food, or other rubbish belonging to him, and burn it with certain formalities; and so the man falls ill and sends a present-an embryo sacrifice-to the sorcerer or embryo god, praying him to stop burning the rubbish, for he believes that when it is quite burnt he must surely die.' Note what has been read into the facts in stating them, and now note the inferences drawn from both. "Here we have all the elements of religion-a god, a worshipper, prayer, and sacrifice-in process of evolution.' ${ }^{\circ}$ To adduce all the 'other facts' that have to be taken into account, and to examine fully the inferences Mr. Frazer draws from his facts, would take up too much space. But take a few points. Dr. Turner, as quoted by Mr. Frazer himself (vol. ii. p. 464), states that the spirits of their departed ancestors are their gods, and that chiefs who reach an advanced age are after death deified, etc. Although he speaks of disease-makers as the real gods at Tanna, he immediately after qualifies or explains this loose use of the word 'gods,' by saying, 'There are rain-makers and thunder-makers, and fly and mosquito-makers, and a host of other "sacred men," but the disease-makers are the most dreaded." Dr. Turner resided only seven months on Tanna, and on his own confession was imperfectly acquainted with the language and traditions of the Tannese. $^{7}$ Dr. J. G. Palon, who had a longer experience and more intimate knowledge, states in his well-known Autobiggraphy, (pt. i. pp. Ir 8 , I 9 , 6th ed. I 890 ) that 'sacred men and women, wizards and witches, received presents regularly to infuence the gotls, and to remove sickness, or to

- G.B." i. 137, cf. $3 \mathrm{I} 7$; and G. Turner, Nindeen I'ears in Pulynesia, pp. 88-92.

${ }^{7} \mathrm{G}$. Turner, Nincteen Years in Folynesia, pp. 68, 69, and SS. 
cause it by the nahak, i.e. incantation, ${ }^{1}$ over remains of food, or the skin of fruit, such as banana, which the person has eaten, on whom they wish to operate.' Dr. Turner himself informs us 'that the belief in the system of naluak-burning was as firm in the craft as out of it. If a disease-maker was ill himself, he felt sure that some one must be burn-

' Dr. Turner mistakenly identifies nahak with rubbish, principally refuse of food, the thing to be 'bewitched'-a mistake a newcomer, whether a traveller or missionary, is very apt to make. ing his nahak. $\mathrm{He}$, too, must have a shell blown and presents sent to the party supposed to be causing the mischief.' 2 The sorcerer of Tanna is not an embryo god, he receives presents to induce him to influence the gods or to stop his own incantations, and though regarded as a 'sacred man.' (? priest), is really the dupe of his own 'sympathetic magic.' A pretty embryo god! He is more likely to evolve into a scientific scavenger.

\title{
Sennacherib's Gecond Expedition to the Wotat, and the

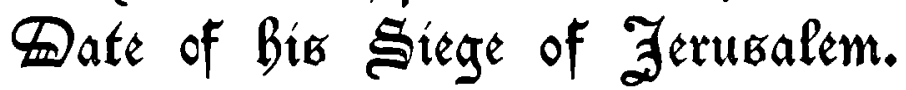

\author{
By Professor J. V. PrAšek, Ph.D., Prague.
}

II.

THE principal merit of having recognized correctly the internal character of the biblical record in question, of having critically distinguished its components, and drawn therefrom the logical conclusions, belongs to B. Stade, who (first in his Gesch. d. V. Isr. i. 617 ff., and afterwards in his well-known examination of the sources in the Z.A.T.W. I 886, p. $1 S_{3} \mathrm{ff}$, which in the main is to be regarded as conclusive) recognizes three independent sources, which are partly represented also in Is $36-3 \mathrm{~S}$, and from which the redactor of the Books of Kings has produced the present form of text.

One must not, indeed, forget Stade's predecessors, who laboured to prepare the rugged path of examination of the sources for the master. Sir H. Rawlinson, as was remarked before, had already shown indirectly that the biblical account ( $2 \mathrm{~K} \mathrm{I}^{13-16}$ ) is to be distinguished from the rest of the narrative relating to Sennacherib's undertakings against Judah, a view which, however, comes to the same thing as the supposition that two distinct sources were afterwards worked up into a single narrative. He was followed by Kleinert (S.K. I $S_{77}$, i. $16_{7}$ ff.), who, however, sought to prove that $2 \mathrm{~K} \times 8^{14-16}$ refers not to the campaign of Sennacherib but to that of Sargon, the name Sennacherib being arbitrarily inserted by the compiler in $v{ }^{13}$, and the section having in view the time of the Assyrian invasion of Palestine, 7 r 3 B.C., on which occasion Ashdod in particular was subdued; cf. Schrader, $K . A . T .^{2}$ 3ro. A more correct view of the state of the case was taken by Wellhausen (in Bleek's Einleit. in. d. A.T. ${ }^{4}{ }_{25} 6$ ), who expresses his conviction that in $2 \mathrm{~K} \mathrm{r}^{14-16}$ on the one hand, and in v. ${ }^{17 \mathrm{ff}}$. On the other, we have accounts of two different stages of the same campaign. Floigl (Die Chronologie der Bibel, $28 \mathrm{ff}$., and also in his Cyrus und Herodot. I $69 \mathrm{ff}$.) regards the narrative of $2 \mathrm{~K} \mathrm{I}^{14-16}$ as the only authentic one, and the other, $I 8^{13 .} 17$ f. $-20^{19}$, as a legendary account put togrether from older material during the Exile, but considers that both narratives, although independently composed, relate to the same event, a view which is maintained also by Nowack (S.K. I $S S_{\text {I, }}$ p. $300 \mathrm{ff}$ ), who, following Kuenen, appeals in support of it to the circumstance that in $2 \mathrm{~K} \times 8^{14-16}$ we find uniformly the form הin, whereas in the other passage in Kings as well as in Is $3^{6-39}$ we have always חוקיהו.

None of the views cited could rise to the height of H. Rawlinson's explanation, because even that which is the condition of all advance, namely, the distinguishing of two original accounts in the Bible narrative, cannot arrive at the correct conception of the circumstances of the case without the only possible conclusion that the different sources have in view different events. Stade has the merit of being the first to place the investigation of Sennacherib's relations with the West of Palestine upon the footing it had already gained at the beginning of ancient Eastern monumental research, through 